\title{
Effect of processing parameters on the proximate composition and sensory characteristics of breadfruit 'elubo'
}

\author{
Tijani Akeem Olumide ${ }^{1}$, Bakare Henry Adegoke ${ }^{2}$, \\ Oke Emmanuel Kehinde' ${ }^{3}$, Oyedeji Ajibola Bamikole ${ }^{4}$
}

\author{
1 - National Biotechnology Development Agency, Owode Yewa, Ogun state, Nigeria \\ 2 - Department of Hospitality and Tourism, Federal University of Agriculture, Abeokuta, \\ Nigeria
}

3 - Department of Food Science and Technology, Federal University of Agriculture,

Abeokuta, Nigeria

4 - Department of Biotechnology and Food Technology, Durban University of

Technology, Durban, South Africa

Keywords:

Breadfruit

Elubo

Processing

Sensory

\section{Article history:}

Received 16.10.2016

Received in revised

form 29.11.2016

Accepted 27.12.2016

\section{Corresponding author:}

Oke Emmanuel Kehinde E-mail:

kennyoke35@gmail.com

DOI: $10.24263 / 2304-$

974X-2016-5-4-9

\section{Abstract}

Introduction. Breadfruit is an underutilized fruit and its utilization as food can be improved by converting it to indigenous foodstuff like elubo that has an established processing technology.

Materials and methods. The breadfruit were washed in clean water to remove adhering latex and dirt, peeled manually and chopped. The chopped breadfruit was parboiled in water at 30,50 and $60{ }^{\circ} \mathrm{C}$ for 90,120 and $150 \mathrm{~min}$. The parboiled breadfruit was steeped for 6,12 and $18 \mathrm{hrs}$. The steeped breadfruit was drained, dried in the cabinet dryer at $60{ }^{\circ} \mathrm{C}$ for 2 days and milled into flour (elubo) while the breadfruit paste (Amala) produced from the breadfruit flour (elubo) was subjected to sensory analysis.

Results and discussion. The moisture content of breadfruit elubo varied between 9.07 and $12.20 \%$. The moisture content of a food sample reflects the amount of solid matter in the sample. The high ash content of breadfruit elubo (BE) is an indicative of being a good source of mineral for the flour. The values of the ash content varied between 2.00 and $2.90 \%$. The fibre content of the breadfruit elubo varied between 2.86 to $3.60 \%$. Parboiling temperature, parboiling time and steeping time does not significantly ( $p>0.05)$ affects the fibre content of the breadfruit elubo. The protein content of breadfruit elubo varied between 3.80 and $5.42 \%$. The protein content of the breadfruit elubo decrease irrespectively of parboiling temperature, parboiling time and steeping time. The carbohydrate content for the breadfruit elubo varied from 73.67 to $78.33 \%$. High carbohydrate content in food implies the food is a high in calorie. The carbohydrate content of the breadfruit elubo is not significantly $(\mathrm{p}>0.05)$ affected by the parboiling temperature, parboiling time and steeping time. The Sensory parameters of breadfruit paste prepared from breadfruit elubo were significantly $(p<0.05)$ different from paste of yam elubo $(\mathrm{t}$-value $=2.523$, degree of freedom $=14, \mathrm{p}$ value $=0.01$, one tailed).

Conclusion. The result revealed that breadfruit elubo has high fibre and carbohydrate content which implies that breadfruit elubo can serves as high energy food. 


\section{Introduction}

Elubo is obtained from the conversion of yam tubers into fine flour and the unit operations involved include harvesting, sorting, peeling, slicing, blanching, drying and milling. The resulting product is a white to cream flour, which can be stored for months [1]. The quality of elubo is dependent on the process parameters adopted for its production. Elubo can be processed into a thick consistency food popularly called "Amala" which is prepared by reconstituting (cooking and stirring with boiling water) fermented or unfermented yam flour (elubo) to achieve starch gelatinization [2, 3, 4]. Amala primarily contains carbohydrates and as a result, it does not provide adequate nutrition. Amala prepared from yam flour contribute more than 200 dietary calories per capita daily for more than 150 million people in West Africa and serve as an important source of income [5].

In Nigeria, yam is the second most important source of carbohydrate after cassava [6].Nigeria is the highest producer of yam in the World [7] producing about 38 million tonnes per annum [8] which is well over half of the world's yams [9]. It is a seasonal crop that has competing domestic culinary uses and therefore attracts relatively higher prices during off-season period. One way to minimize this higher price during off-season period is the use of under utilized crops in the production of elubo, for the purpose of providing cheap and unrestricted access to this staple food.

Breadfruit (Artocarpus altilis) is a tropical fruit native to Malaysia and countries of the South Pacific and the Caribbean and it is an important food in these areas [10]. Breadfruits are found from sea level to about $1550 \mathrm{~m}$ elevation. It has been reported that breadfruit yields in terms of food are superior to other starchy staples such as cassava and yam [11]. The mature fruit is a good source of carbohydrate (84\%) with starch constituting more than $60 \%$ of the total carbohydrate [12].The bread fruit pulps are made into various dishes; it can be processed into flour and used in bread and biscuit making [13]. Breadfruit has also been reported to be rich in fat, ash, fibre and protein [14]. Despite the importance of this fruit, its production is faced with several problems including short shelf life and poor yield due to diseases [15]. The fruits are utilized in Nigeria within 5days of harvesting because of their short shelf lives. One way to minimize post-harvest losses and increase the utilization of breadfruit is by processing into flour, which is a more stable intermediate product. Its utilization can be enhanced by converting it to elubo, which is the starting material for processing through reconstitution with hot water to form a paste or dough. In Nigeria, breadfruit is regarded as the poor man's substitute for yam (D. Rotundata or D. Alata), because it can be used in the preparation of several foodsfor which yam was a traditional crop of choice. It also costs less than one third the price of procuring yam [16].

Extensive research from yam and cassava for "elubo" have been reported by several authors $[173,18,4,19]$. Information is however scanty on the use of breadfruit for "elubo" production. Also, if the existing technology for the production of yam elubo (YE) is to be adapted for breadfruit elubo (BE), it would be necessary to explore the effect of critical processing parameters on the some quality attributes of the elubo and the paste made from its reconstitution. This study therefore investigated the optimum processing conditions required for the production of breadfruit elubo using response surface methodology (RSM), and the sensory acceptability of the breadfruit elubo (BE) paste (Amala)compared to the one made from yam elubo (YE). 


\section{Materials and methods}

\section{Materials}

Freshly harvested matured breadfruits were purchased from a local market in Idiroko, Ogun State, Nigeria. Equipment used include cabinet dryer, laboratory milling machine, mechanical sieve, digital weighing balance, stirrer, knife, bucket and stainless steel perforated tray, stainless steel pot, electric cooker were obtained from the Food processing Laboratory of Department of Food Science and Technology, Federal University of Agriculture, Abeokuta, Nigeria.

\section{Methods}

\section{Production of breadfruit flour ("elubo")}

The method described by [4] for the production of yam flour elubo was adopted, with variation in parboiling time, parboiling temperature and steeping time. The fruits were washed in clean water to remove adhering latex and dirt, peeled manually and chopped. The chopped breadfruit was parboiled in water at 30,50 and $60^{\circ} \mathrm{C}$ for 90,120 and $150 \mathrm{~min}$. The parboiled breadfruit was steeped for 6,12 and $18 \mathrm{hrs}$. The steeped breadfruit was drained and dried in the cabinet dryer at $60^{\circ} \mathrm{C}$ for 2 days. The dried breadfruit was milled using laboratory milling machine (Fritsch, D-55743, Idar-oberstein-Germany). The milled sample was sieved using $250 \mu \mathrm{m}$ screen and stored in air-tight polyethylene bags.

\section{Preparation of Breadfruit Paste (Amala)}

"Amala" was prepared from breadfruit flour using the method described by [20]. Breadfruit paste (Amala) was prepared by adding 200g of breadfruit flour (elubo) to $200 \mathrm{ml}$ of boiling water in a stainless pot. The paste was stirred manually with a wooden spoon over a low flame until a smooth consistency was attained.

\section{Experimental design and process optimization}

Box-Behnken design [21] was used for the experiment. The three independent variables used for the process optimisation were parboiling temperature (X1), parboiling time $(X 2)$ and steeping time $(X 3)$. Design Expert software version 7.00 (Stat Ease Inc., Minneapolis, MN, USA). The three levels established for each of the independent variables based on a series of preliminary experiments were coded as $-1,0$, and 1 with their actual values in Table 1. The design consists of 17 experimental runs to which the dependent variables (Responses) were fitted after the laboratory experiments. The measured responses were the proximate composition (Moisture, ash, protein, fibre and carbohydrate)

Experimental data were fitted to a second order polynomial model and regression coefficient the various responses were obtained. The generalized second-order polynomial used in response surface analysis was.

Where $Y$ is the response, $\beta_{0}$ is the intercept, where $\beta_{1}, \beta_{2}$ and $\beta_{3}$ are linear, quadratic and interaction coefficients respectively, $x_{1}, x_{2}, x_{3}$ are the various independent variables and $€$ is the error. The statistical significance of the terms in the regression equations was examined by analysis of variance (ANOVA) for each of the responses. The design expert software was used to generate response surfaces models graphs showing the relationship between the independent variable and the responses while holding a variable constant. The parameters were optimized by using the numerical method of RSM based on desirability concept to obtain range of optimised solutions which were used for the verification experiments to determine the validity of the model. 
Table 1

The coded values for the independent variables

\begin{tabular}{|l|l|l|l|l|}
\hline $\begin{array}{l}\text { Processing } \\
\text { Variables }\end{array}$ & Variable & $\mathbf{- 1}$ & $\mathbf{0}$ & $\mathbf{+ 1}$ \\
\hline Parboiling temperature $\left({ }^{\circ} \mathrm{C}\right)$ & $(\mathrm{X} 1)$ & 45 & 30 & 60 \\
\hline Parboiling time $(\mathrm{min})$ & $(\mathrm{X} 2)$ & 120 & 90 & 150 \\
\hline Steeping time $(\mathrm{h})$ & $(\mathrm{X} 3)$ & 6 & 12 & 18 \\
\hline
\end{tabular}

Table 2

Response surface analysis different experimental runs

\begin{tabular}{|c|c|c|c|}
\hline $\begin{array}{c}\text { Experimental } \\
\text { Runs }\end{array}$ & $\begin{array}{c}\text { Parboiling } \\
\text { temperature } \\
\text { (X1) } \\
{ }^{\circ} \mathrm{C}\end{array}$ & $\begin{array}{c}\text { Parboiling time } \\
\text { (X2), } \\
\text { min }\end{array}$ & $\begin{array}{c}\text { Steeping time } \\
\text { (X3), } \\
h\end{array}$ \\
\hline 1 & 60 & 150 & 12 \\
\hline 2 & 45 & 90 & 6 \\
\hline 3 & 60 & 120 & 6 \\
\hline 4 & 30 & 150 & 12 \\
\hline 5 & 45 & 90 & 18 \\
\hline 6 & 45 & 120 & 6 \\
\hline 7 & 30 & 120 & 6 \\
\hline 8 & 45 & 120 & 12 \\
\hline 9 & 30 & 90 & 12 \\
\hline 10 & 45 & 150 & 18 \\
\hline 11 & 45 & 120 & 12 \\
\hline 12 & 30 & 120 & 18 \\
\hline 13 & 60 & 12 & 18 \\
\hline 14 & 45 & 120 & 12 \\
\hline 15 & 45 & 150 & 6 \\
\hline 16 & 45 & 120 & 12 \\
\hline 17 & 60 & 90 & 12 \\
\hline
\end{tabular}

\section{Determination of proximate composition of breadfruit elubo}

Moisture content and crude fibre content of breadfruit elubo were determined by AOAC method. Crude protein was determined by the standard khjeldahl method, AOAC method. Fat content of the samples were measured using Soxhlet extraction method according to AOAC method. Ash content was determined by igniting $5 \mathrm{~g}$ of sample in a furnace for 4 hours at $550{ }^{\circ} \mathrm{C}$ until light grey ash colour and constant weight was achieved by [22].Carbohydrate content were determined by difference method. The analyses were carried out in triplicates.

\section{Sensory evaluation of breadfruit paste (Amala)}

Simple paired comparison was used to compare the difference between amala made from breadfruit elubo (BE) and yam elubo (YE). Thirty untrained panelists were asked to rate the colour, mouldability, taste, aroma, smoothness, elasticity, stickiness and hardness of the respective amala samples 


\section{Statistical analysis}

Apart from the statistical method used as an integral part of the RSM. Independent ttest was also used to evaluate the result of the sensory analysis conducted on the amala.

\section{Results and discussion}

\section{Effect of process variables on moisture content of breadfruit elubo (BE)}

In Table 3, the regression coefficients of the quadratic models for the response variable, along with the corresponding p-value are presented. Coefficient values less than 0.05 indicated that the model was significant. In this case, the linear coefficient of parboiling temperature $\left(\mathrm{X}_{1}\right)$, steeping time $\left(\mathrm{X}_{3}\right)$ had a significant impact on the moisture content. The quadratic effects of the parboiling temperature, time and steeping time had negative significant $(p<0.05)$ effect on the moisture content. However, the interactive effects of all the process variables except for parboiling temperature and steeping time $\left(\mathrm{X}_{1} \mathrm{X}_{3}\right)$ had no significant $(\mathrm{p}>0.05)$ impact on the moisture content. Moisture content of breadfruit elubo varied between 9.07 and $12.20 \%$. The moisture content of a food sample reflects the amount of solid matter in the sample. The higher the moisture content, the higher the rate of spoilage. Adebowale et al., [23] stated that moisture content is a measure of the water content and also an indicator of shelf stability. Figure 1 shows the effect of the process variables on the moisture content of breadfruit elubo. From the figure, increase in parboiling temperature (PT) and parboiling time (Pt) brought about an increase in moisture content at constant steeping time (ST). A similar trend was observed when increasing ST and PT using a constant level of Pt. From the results, at a higher ST and Pt, there was an increase in moisture content of the breadfruit elubo. This may be as a result of decrease in porosity which will lead to an increase in moisture content. The higher moisture content observed for breadfruit elubo may be due to the thick slices $(50-60 \mathrm{~mm})$ used. Babajide et al., [4] earlier reported that thick slices $(30-50 \mathrm{~mm})$ had significant higher moisture content than slices less than $30 \mathrm{~mm}$. Increase in moisture content can enhance microbial growth which leads to deterioration in foods. FAO [6] recommended a safe level of 12 to $14 \%$ moisture content for flour or powdered food

Regression Coefficients for moisture content of BE

Table 3

\begin{tabular}{|l|c|c|c|}
\hline Factors & Coefficient Estimate & Standard error & p-values \\
\hline Constant & 12.16 & 0.078 & $<0.0001$ \\
\hline Parboiling Temp $\left(\mathrm{x}_{1}\right)$ & $0.096^{*}$ & 0.061 & 0.1605 \\
\hline Parboiling Time $\left(\mathrm{x}_{2}\right)$ & 0.14 & 0.061 & 0.0547 \\
\hline Steeping Time $\left(\mathrm{x}_{3}\right)$ & $1.37^{*}$ & 0.061 & $<0.0001$ \\
\hline P Temp·P Time $\left(\mathrm{x}_{1} \mathrm{x}_{2}\right)$ & 0.013 & 0.087 & 0.8894 \\
\hline P Temp·S Time $\left(\mathrm{x}_{1} \mathrm{x}_{3}\right)$ & $-0.25^{*}$ & 0.087 & 0.0236 \\
\hline P Time·S Time $\left(\mathrm{x}_{2} \mathrm{x}_{3}\right)$ & 0.030 & 0.087 & 0.7395 \\
\hline P Temp·P Temp $\left(\mathrm{x}_{1}{ }^{2}\right)$ & $-0.81^{*}$ & 0.085 & $<0.0001$ \\
\hline P Time·P Time $\left(\mathrm{x}_{2}{ }^{2}\right)$ & $-1.03^{*}$ & 0.085 & $<0.0001$ \\
\hline S Time·S Time $\left(\mathrm{x}_{3}{ }^{2}\right)$ & $-0.52^{*}$ & 0.085 & 0.0004 \\
\hline
\end{tabular}

*Significant at $\mathrm{p}<0.05, \mathrm{P}=$ parboiling, $\mathrm{x}_{1}=$ parboiling temperature, $\mathrm{x}_{2}=$ parboiling time and $\mathrm{x}_{3}=$ steeping time 

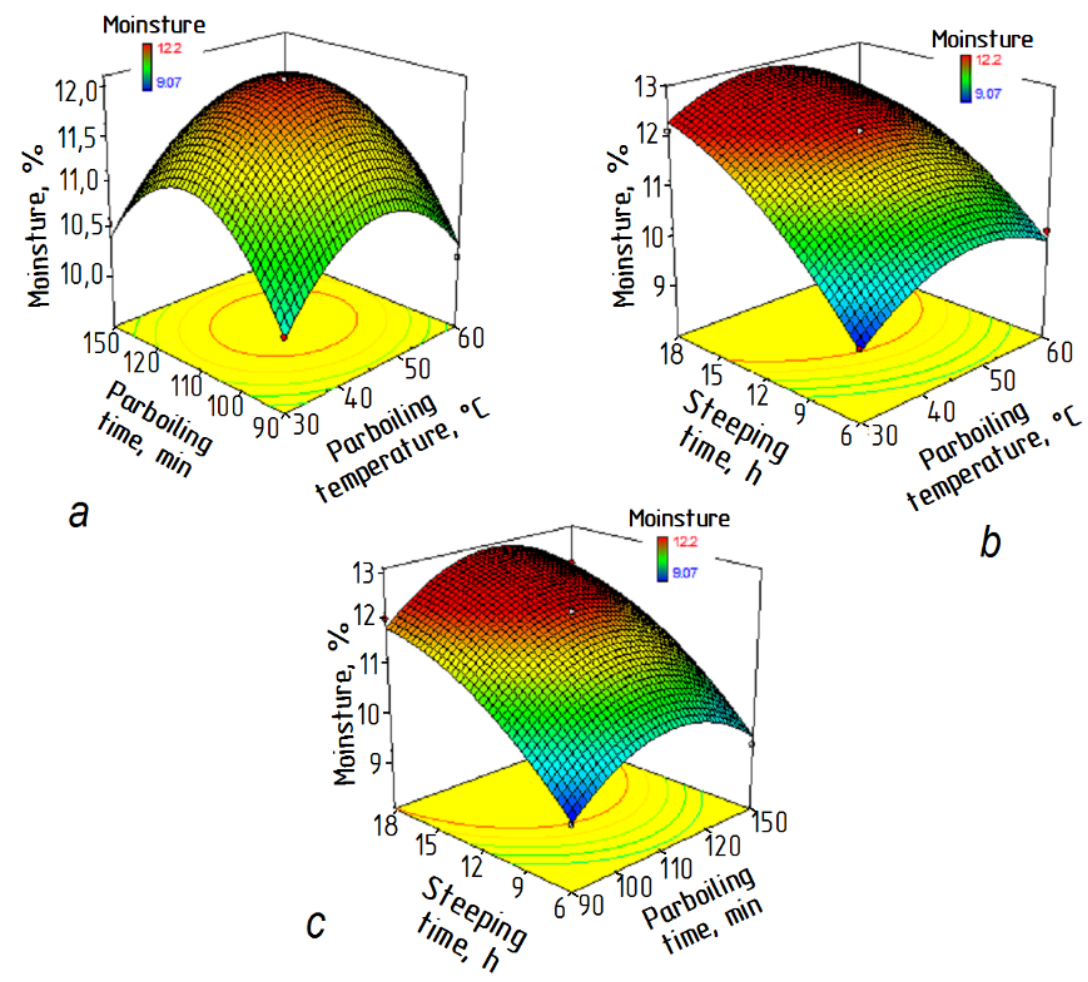

$b$

Figure 1. Response surface plot for Moisture content (\%) of BE

$(a-$ steeping time $=12 ; b-$ parboiling time $-120 ; c-$ parboiling temperature $=45)$

\section{Effect of process variable on protein content of breadfruit elubo (BE)}

An acceptable second-order polynomial regression equation (2) as a function of parboiling temperature, time and steeping time was generated for the protein content after the removal of non-significant terms as follows:

$$
Y=4.41+0.04 X_{2}-0.77 X_{3}+0.36 X_{1}^{2}-0.36 X_{2}^{2}-0.19 X_{3}^{2}
$$

where $X_{1}, X_{2}$ and $X_{3}$ represent coded values of parboiling temperature and steeping time, respectively and $\mathrm{Y}$ is the response variable (BE protein content).

In table 4, the regression coefficients of the quadratic models for the response variable, along with the corresponding p-value were presented. Coefficient values less than 0.05 indicate that the model is significant. In this case, the linear coefficient of parboiling time $\left(\mathrm{X}_{2}\right)$, steeping time $\left(\mathrm{X}_{3}\right)$ had a great impact on the protein content. The quadratic effects of the parboiling temperature, time and steeping time had negative significant $(\mathrm{p}<0.05)$ effect on the protein content. However, the interactive effects of all the process variables had no significant $(\mathrm{p}>0.05)$ impact on the protein content. The protein content of the breadfruit elubo varied between 3.80 and $5.42 \%$, within the experimental conditions. The response surface plots for protein content at different experimental conditions are presented in Figure 2. From the figures, it can be observed that increasing PT and Pt at constant ST decreases protein content at constant Pt increase in ST and PT results in low protein content. Also, increasing ST and Pt when PT is constant lowers the protein content of the breadfruit elubo. 
The effect of parboiling and steeping on the protein content of the breadfruit elubo probably maybe due to the denaturation of protein caused by the effect of heat on the breadfruit slices during parboiling. This is an indication that protein content of breadfruit flour can be influenced by using appropriate set of processing parameters. This shows that protein content will decrease irrespectively of parboiling temperature, parboiling time and steeping time [27].

Table 4

Regression coefficient for protein content of BE

\begin{tabular}{|l|c|c|c|}
\hline Factors & Coefficient Estimate & Standard error & p-values \\
\hline Constant & 4.41 & 0.018 & $<0.0001$ \\
\hline Parboiling Temp $\left(\mathrm{x}_{1}\right)$ & 0.02 & 0.014 & 0.3186 \\
\hline Parboiling Time $\left(\mathrm{x}_{2}\right)$ & $0.04^{*}$ & 0.014 & 0.0313 \\
\hline Steeping Time $\left(\mathrm{x}_{3}\right)$ & $-0.77^{*}$ & 0.014 & $<0.0001$ \\
\hline P Temp·P Time $\left(\mathrm{x}_{1} \mathrm{x}_{2}\right)$ & 0.00 & 0.020 & 1.0000 \\
\hline P Temp·S Time $\left(\mathrm{x}_{1} \mathrm{x}_{3}\right)$ & -0.02 & 0.020 & 0.3451 \\
\hline P Time·S Time $\left(\mathrm{x}_{2} \mathrm{x}_{3}\right)$ & -0.03 & 0.020 & 0.1727 \\
\hline P Temp·P Temp $\left(\mathrm{x}_{1}{ }^{2}\right)$ & $0.36^{*}$ & 0.019 & $<0.0001$ \\
\hline P Time·P Time $\left(\mathrm{x}_{2}{ }^{2}\right)$ & $0.36^{*}$ & 0.019 & $<0.0001$ \\
\hline S Time·S Time $\left(\mathrm{x}_{3}{ }^{2}\right)$ & $-0.19^{*}$ & 0.019 & $<0.0001$ \\
\hline
\end{tabular}

*Significant at $\mathrm{p}<0.05, \mathrm{P}=$ parboiling, $\mathrm{x}_{1}=$ parboiling temperature, $\mathrm{x}_{2}=$ parboiling time and $\mathrm{x}_{3}=$ steeping time
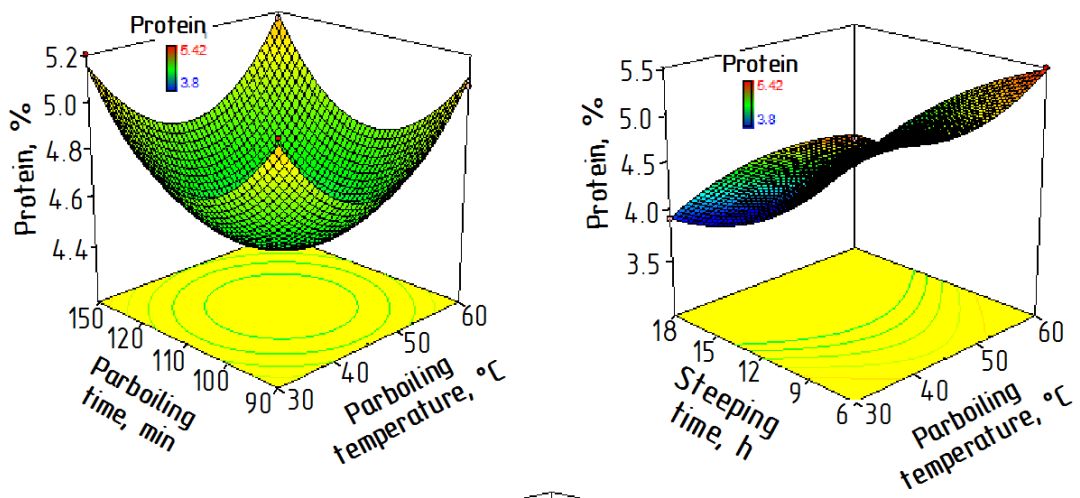

a

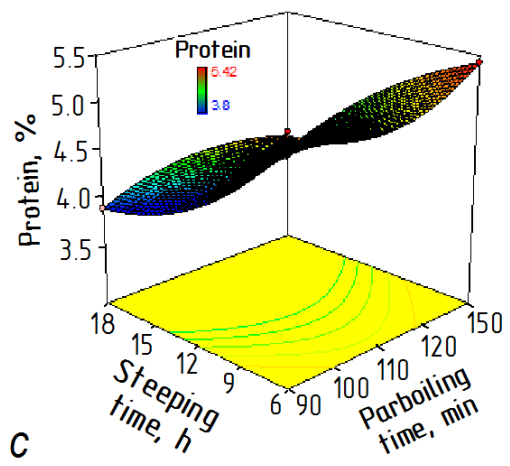

$b$

Figure 2. Response surface plot for Protein (\%) content of BE

$(a-$ steeping time $=12 ; b-$ parboiling time $-120 ; c-$ parboiling temperature $=45)$ 


\section{Effect of process variable on ash content of breadfruit elubo (BE)}

In table 5 , the regression coefficients of the quadratic models for the response variable, along with the corresponding p-value were presented. Coefficient values less than 0.05 indicate that the model is significant. The quadratic, interactive and the linear effect has no significant effect on the ash content. The values of ash content for breadfruit elubo varied between 2.00 and $2.92 \%$. Ash content is a reflection of mineral status, even though contamination can indicate a high concentration in a sample. The ash content of breadfruit elubo (BE) was higher than 2.07\% reported for sweet potatoes elubo by Fetuga et al., [20] and $2.03 \%$ reported by Babajide et al., [24] for yam elubo. The high ash content of the flour is indicative of being a good source of minerals. Breadfruit elubo would therefore, be a better source of minerals than sweet potatoes and yam elubo. Figure 3 shows the effect of the process variable on the ash content of breadfruit elubo. From the figure, It was observed that increasing PT and decrease in Pt when ST is constant increases ash content while decreasing ST and increasing PT at constant Pt increases ash content. At a constant PT, increase in ST and Pt decreased the ash content of the breadfruit elubo. This maybe because of the leaching of soluble minerals from the breadfruit [4]

Table 5

Regression coefficient for ash content of BE

\begin{tabular}{|l|c|c|c|}
\hline Factors & Coefficient Estimate & Standard error & p-values \\
\hline Constant & 3.09 & 0.081 & 0.2391 \\
\hline Parboiling Temp $\left(\mathrm{x}_{1}\right)$ & -0.07 & 0.064 & 0.8072 \\
\hline Parboiling Time $\left(\mathrm{x}_{2}\right)$ & -0.01 & 0.064 & 0.3275 \\
\hline Steeping Time $\left(\mathrm{x}_{3}\right)$ & 0.11 & 0.064 & 0.1194 \\
\hline P Temp $P$ Pime $\left(\mathrm{x}_{1} \mathrm{x}_{2}\right)$ & 0.04 & 0.064 & 0.9153 \\
\hline P Temp·S Time $\left(\mathrm{x}_{1} \mathrm{x}_{3}\right)$ & -0.13 & 0.091 & 0.6916 \\
\hline P Time $\cdot \mathrm{S}$ Time $\left(\mathrm{x}_{2} \mathrm{x}_{3}\right)$ & $-2.5 \cdot 10^{-3}$ & 0.091 & 0.0496 \\
\hline P Temp $\cdot \mathrm{P}$ Temp $\left(\mathrm{x}_{1}{ }^{2}\right)$ & 0.11 & 0.091 & 0.1826 \\
\hline P Time $P$ Time $\left(\mathrm{x}_{2}{ }^{2}\right)$ & -0.14 & 0.088 & 0.1658 \\
\hline S Time $\cdot S$ Time $\left(\mathrm{x}_{3}{ }^{2}\right)$ & -0.06 & 0.088 & 0.3146 \\
\hline
\end{tabular}

*Significant at $\mathrm{p}<0.05, \mathrm{P}=$ parboiling, $\mathrm{S}=$ steeping, $\mathrm{x}_{1}=$ parboiling temperature, $\mathrm{x}_{2}=$ parboiling time and $\mathrm{x}_{3}=$ steeping time

\section{Effect of process variable on crude fibre content of breadfruit elubo (BE)}

The quadratic effect linear effect and the interaction effect of the parboiling temperature, parboiling time and steeping time does not significantly $(\mathrm{p}>0.05)$ affects the fibre content of the BE. The fibre content of breadfruit elubo varied between 2.86 to $3.60 \%$. The fibre content of breadfruit elubo was higher than yam elubo (1.65\%) reported by Babajide et al., [24], but lower than 3.2\% reported by Fetuga et al., [20] for sweet potato elubo. Fibre is reported to plays a significant role in the prevention of several diseases such as; cardiovascular diseases, diverticulosis, constipation, irritable colon, cancer and diabetes $[25,26]$. Figure 4 shows the response surface plots for the crude fibre at different experimental condition. From the figure, it was observed that increasing PT and Pt when steeping time is constant decreases fibre content while increasing ST and PT at constant Pt increases fibre content. At a constant PT, increase in ST and Pt increases the fibre content of the breadfruit elubo. It was shown that parboiling temperature, parboiling time and steeping time does not significantly $(\mathrm{p}>0.05)$ affects fibre content of the breadfruit, this was in accordance with Adejumo et al., [27]. 

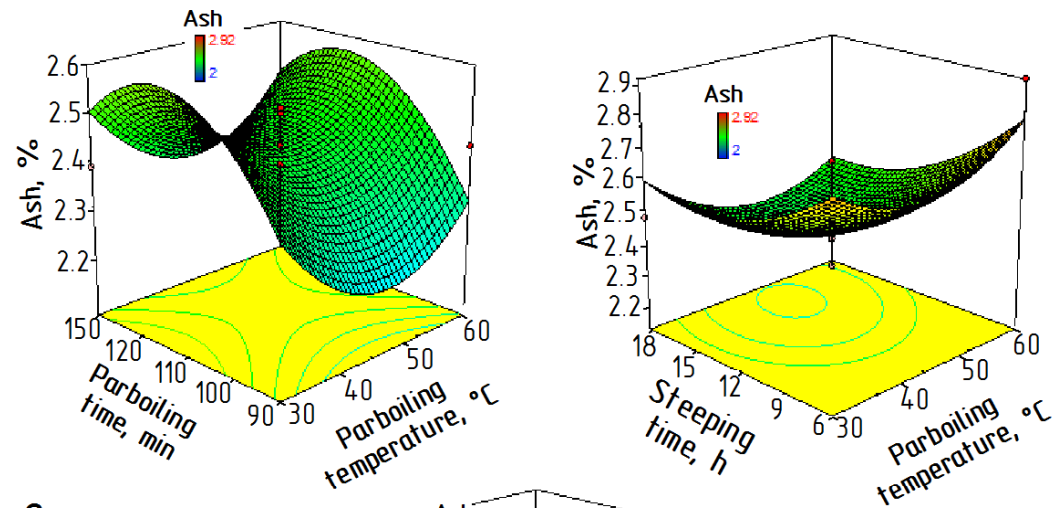

a

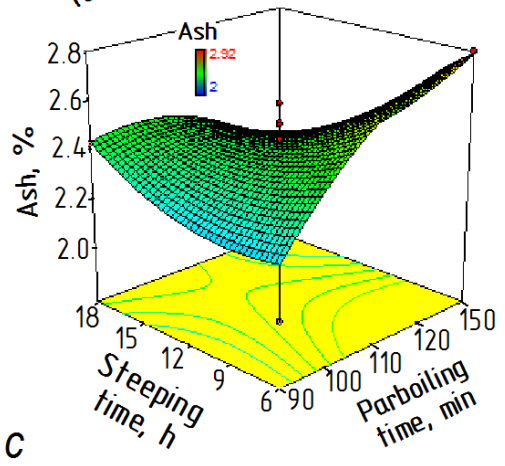

$b$

Figure 3. Response surface plot for Ash (\%) content of BE

$(a-$ steeping time $=12 ; b-$ parboiling time $-120 ; c-$ parboiling temperature $=45)$
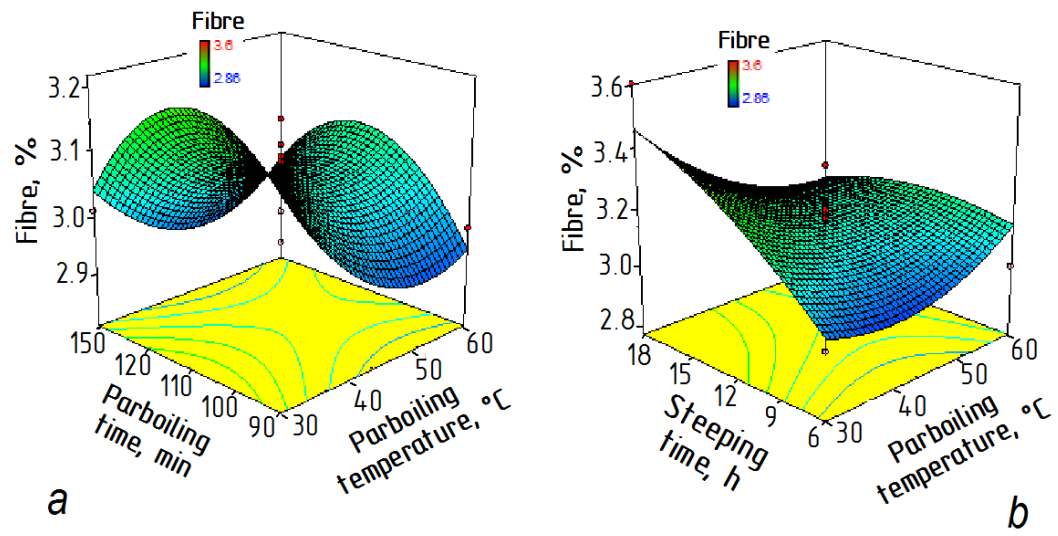

Figure 4. Response surface plot for Fibre (\%) content of BE $(a-$ steeping time $=12 ; b-$ parboiling time -120$)$ 


\section{Effect of process variable on carbohydrate content of breadfruit elubo (BE)}

The main effect and the interaction effect of the parboiling temperature, parboiling time and steeping time does not significantly ( $p>0.05)$ affects the carbohydrate content of the $\mathrm{BE}$. The carbohydrate content for the breadfruit elubo ranged from 73.67 to $78.33 \%$. High carbohydrate content in food implies the food is a high in calorie. The carbohydrate of the breadfruit elubo in this research is lower than Fetuga et al., [20], which reported a value of $87.68 \%$ for sweet potatoes elubo. The response surface plots for carbohydrate content at different experimental conditions are presented in Figure 5. It was observed that increasing PT and Pt at constant ST resulted in decrease in carbohydrate content increasing ST and PT at constant Pt decreases carbohydrate content. At a constant PT, increase in ST and Pt decreases the carbohydrate content of the breadfruit elubo. The carbohydrate content of the breadfruit elubo is not significantly ( $>0.05$ ) affected by the parboiling temperature, parboiling time and steeping time. The result obtained in this work is similar to the findings of Akissoe et al., [28], which reported that different cultivars have varied carbohydrate content of yam elubo.

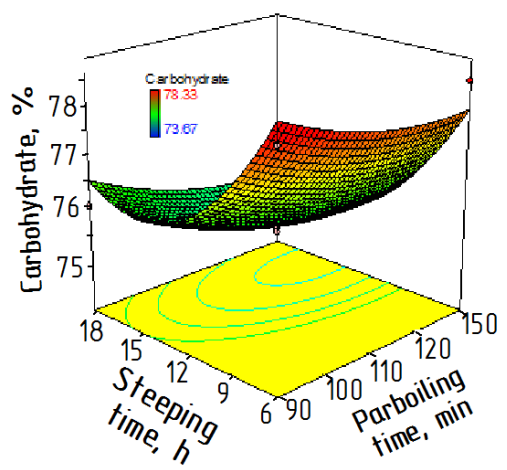

Figure 5. Response surface plot for Carbohydrate (\%) content of BE (parboiling temperature $=45$ )

\section{Comparison of amala made from breadfruit elubo and yam elubo}

The mean difference between conditions was 5.00 and the $95 \%$ confidence interval for the estimated population is between 0.68 and 6.57 . The independent t-test showed that the difference between conditions were significantly different ( $\mathrm{t}$-value $=2.523$, degree of freedom $=14$, $p$-value $=0.01$, one tailed). This implies that the sensory attribute of cooked paste prepared from breadfruit elubo were different from paste of yam flour. This could be due to the familiarity of the panel to traditionally processed yam paste (amala) which is free from odour, stickier, and darker in colour than breadfruit amala.

\section{Conclusion}

It can be inferred from this study that breadfruit elubo can be developed into a cooked paste (Amala). Response surface methodology was successfully utilized for optimization of the proximate composition of breadfruit elubo. However, the breadfruit elubo has high fibre and carbohydrate content which implies that breadfruit elubo can serve as high energy food and can be used to improve the health benefit of the consumer. 


\section{Reference}

1. Adedeji K.K. (2010), Physical, functional and sensory properties of yam flour 'elubo' obtained from Kuto- market, Abeokuta. B.Sc Thesis, Federal University of Agriculture, Abeokuta.

2. Akingbala J.O., Oguntimien T.B, Sobande A.O. (1995), Physio-chemical properties and acceptability of yam flour substituted with soy flour, Plant Food for Human Nutrition, 48, pp. 73-80.

3. Akissoe N., Hounhouigan D.J., Bricas N., Vervier P., Nago C.M, Olorunda A. (2001), Physical, chemical and sensory evaluation of dried yam (Dioscorea cayenensis rotundata) tubers, flour, and amala a flour-derived product, Tropical Science, 4, pp. 151-155.

4. Babajide J. M., Henshaw F.O, Oyewole O.B. (2006), Effect of Processing Variables on the Quality of Traditional Dry Yam Slices, European Journal of Science, 14, pp. 102-113.

5. Babaleye T. (2003), Raising the status of the yam, a major food crop in West Africa, Anbbia supplement issue/edition, No. 463.

6. F.A.O. (1994), Tropical root and tuber crops. In: Production, perspectives and future prospects. FAO plant production and protection paper, 126, Rome, Italy.

7. F.A.O. (2008), Food and agriculture organisation. Action programme for the prevention of food losses, improving post-harvest handling, storage and processing of root and tuber crops, Rome, Italy.

8. F.A.O. (2012), Production yearbook, vol. 55, collection FAO statistics, No. 170. $F A O$, Rome, Italy.

9. Onwueme I.C. (1978), The tropical root crops, John Wiley and Sons, New York.

10. Taylor M.B, Tuia V.S. (2007), Breadfruit in the pacific region, Acta Horticulturae, 757, pp. 43-50.

11. Singh H. (2009), Tapping into breadfruit 's bounty, Available at: http://www.universityaffairs.ca/tapping-into-breadfruits_bounty.aspx

12. Oladunjoye I.O., Ologhobo A.D, Olaniyi C.O. (2010), Nutrient composition, energy value and residual anti-nutritional factors in differently processed breadfruit (Artocarpus altilis) meal, African Journal of Biotechnology, 9(27), pp. 4259-4263.

13. Amusa N.A., Kehinde I.A, Ashaye O.A. (2002), Bio-deterioration of breadfruit (Artocarpus communis) in storage and its effects on the nutrient composition, African Journal of Biotechnology, 1(2), pp. 57-60.

14. Ragone D. (1997), Breadfruit (Artocarpus altilis): Promoting the conservation and use of underutilized and neglected crops, Institute of plant genetics and crop plant research, Gatersleben International Plant Genetic Resources Institute, Rome.

15. Olaoye O.A., Onilude A.A, Oladoye C.O. (2007), Breadfruit flour in biscuit making: Effects on product quality, African Journal of Food Science, pp. 20-23.

16. Olutayo M.M., John O. A., Gail S.O., Baccus H.T, Sydney T.O. (2003), Evaluation of breadfruit (Artocarpus communis) in traditional stiff porridge foods, Food, Agriculture and Environment, 1(2), pp. 54-59.

17. Oyewole O.B, Odunfa S.A. (1988), Microbiological Studies on Cassava Fermentation for Lafun Production, Food Microbiology, 5, pp.125-133.

18. Mestres C., Dorthe S., Akissoe N, Hounhouigan J.D. (2004), Prediction of sensorial properties (colour and taste) of amala: A paste from yam chips flour of 
West Africa, through flour biochemical properties", Plant Foods Human Nutrition, 59, pp. 93-99.

19. Nwabueze T.U, Odunsi F.O. (2007), Optimization of process conditions for cassava (Manihot esculenta) lafun production, African Journal of Biotechnology, 6, pp. 603-611.

20. Fetuga G.O., Tomlins K., Bechoff A., Henshaw F.O., Idowu M.A, Westby A. (2014), Effect of variety and processing method on functional properties of traditional sweet potato flour (elubo) and sensory acceptability of cooked paste (amala), Food Science and Nutrition, 2(6), pp. 682-691.

21. Box G.E.P, Behnken D.W. (1960), Some New Three Level Designs for the Study of Quantitative Variables, Technometrics, 2, pp. 455-462.

22. AOAC. (2000), Official methods of analysis. $17^{\text {th }}$ edn., The Association of Official Analytical Chemists, Virginia.

23. Adebowale A.A., Sanni L.O, Awonorin S. O. (2005), Effects of texture modifiers on the physicochemical and sensory properties of dried fufu, International Journal of Food Science and Technology, 11(5), pp. 373-382.

24. Babajide J.M., Oyewole O.B, Obadina A.O. (2005), An assessment of the microbiological safety of dry yam (gbodo) processed in south west Nigeria, African Journal of Biotechnology, 5(2), pp. 157-161.

25. Slavin J.L. (2005), Dietary fibre and body weight, Journal of Nutrition, 21, pp. 411-418.

26. Elleuch M., Bedigian D., Roiseux O., Besbes S., Blecker C., Attia H. (2011), Dietary fibre and fibre-rich by-Products of food processing: characterization, technological functionality and commercial applications: A Review, Food Chemistry, 124, pp. 411-421.

27. Adejumo B.A., Okundare R.O., Afolayan O.I, Balogun S.A. (2013), Quality attributes of yam flour (elubo) as affected by blanching water temperature and soaking time, The International Journal of Engineering and Science, 2(01), pp. 216-221.

28. Akissoe W.H., Hounhouigan J.D., Mestres C., Nago M. (2003), How blanching and drying affects the colour and functional characteristics of yam (D. cayenesis rotundata) Flours, Food Chemistry, 82, pp. 257-264. 